\title{
MARKETING FARM WOODLOT PRODUCTS
}

\section{By L. S. HAMILTON}

A wise farmer will not kill the goose that lays the golden egg. However, he might be wise to kill the goose that lays no eggs at all. Farm woodlots which are producing substantial annual returns are maintained as good investments. Those woodlots which are not contributing reasonably to farm income are often liquidated to make way for some other form of land use. An important phase of government forestry work in the agricultural areas, therefore, consists of showing woodlot owners how to make the maximum continuous profit from their small forests. Proper management of the bush and proper marketing of the woodlot products are the keys to financial success.

Though provincial government foresters in Ontario have for several years been giving advice in farm woodlot management, practically no assistance has been given in wood marketing. The farmer is generally regarded as a shrewd trader, but this attribute can certainly not be applied to him when selling products from his woodlot. He frequently has little knowledge of the quantity and quality of wood involved, the best uses for the various species, the measurement of logs, prevailing market prices, the location of markets, or the intricacies of a forest product sale contract. He has little opportunity to build up a background of experience for a commercial sale occurs perhaps only once every ten or twenty years-or in some cases perhaps only once in his lifetime. Because of this, he needs marketing assistance. Timber sales in the past have generally not been as profitable to the owner as they should have been due to this lack of knowledge, and these sales frequently seriously impaired the productive capacity of the woodland for many years.

The most common method of timber sale has been to sell cutting rights for a lump sum. Many woodlots were completely slashed off under this system, for the purchasers took medium-sized thrifty stems and polewood sizes. The price established usually applied only to the larger trees and the buyers felt that the smaller trees were a "buckshee" windfall. The prices established rarely came up to the true stumpage values of the wood, for the buyers' estimates were the proverbial "guesstimates" which allowed considerable margin for error and for unforeseen defect or logging difficulties. The owners were in no position to question the estimates or the prices, and it is common knowledge that many woodlots were purchased for far less than their true worth.

In those counties of Southern Ontario where by-laws have been enacted which restrict commercial cutting to trees over a specified diameter (usually around $14^{\prime \prime}$ on the stump), potential timber trees under these sizes are saved. The failings of diameter limit laws are well known and are very apparent in the Galt Zone where they have been in effect for more than three years. There is no gainsaying, however, that they have protected many thrifty, middle-

1 Extengion forester, New York State College of Agriculture, Cornell University, Ithaca, N.Y. Formerly Zone Forester at Hespeler 
aged woodlots from cutting, and that their effect in increasing the education of the woodlot owner has been very noticeable. Lump sum sales to the legal diameter limit are now a very prevalent method of selling timber, and this system is open to almost as much financial abuse as unrestricted lump sum sales.

An increasing number of transactions involve selling timber at a stated price per thousand feet log scale. It is to be hoped that this practice replaces other types of sale for there is much less guesswork involved in measuring logs than in estimating the volume of standing timber and setting a price on it. An increasing number of transactions are effected through a written contract rather than by verbal offer and acceptance of a price, with no other conditions. This practice is also being encouraged by the field foresters of the Department of Lands and Forests. The woodlot management picture is considerably brighter now than a few years ago for many owners are selling marked trees only. They are availing themselves of the services of the Zone Foresters in having their woodlots marked for timber cuttings, improvement cuttings and thinnings. These improved practices would be given added impetus if the woodlot owners were given assistance in marketing so that tree farming would become more profitable.

An experiment in marketing assistance was carried out in 1948-49 by the author in his capacity as Zone Forester with the Ontario Department of Lands and Forests at Galt. This project was patterned on the system used in the State of New Jersey by the Department of Conservation. It was initiated at the suggestion of District Forester I. C. Marritt, who had gained knowledge of the New Jersey system while on a forestry trip to that state. The experimental woodlot, which was owned by Mr. Wm. Kauk, was located on a series of hills overlooking the village of Doon, Ontario.

In October, 1948, Mr. Kauk wrote the Zone Forester requesting advice on the management of his 18-acre bush. Soon afterwards the writer called on him, and together they made a preliminary inspection of this woodlot. It was a fine, ungrazed, well-stocked stand of White Pine, Red Oak, Hemlock and Beech, with smaller amounts of Sugar Maple, Basswood, White Oak and White Ash, closely approaching an all-aged stand. For many years, cutting had been confined to dead and dying trees, and consequently a wood capital of mature and near-mature trees had accrued. Mr. Kauk had recently purchased the farm and wished to realize as much immediate value from the woodlot as possible, without reducing its growing stock too severely. When the proposed project of assistance was outlined to him, he became an enthusiastice co-operator, for Mr. Kauk had no previous experience in marking, estimating or marketing.

An agreement covering the technical services of the Department of Lands and Forests was drawn up and signed. The co-operator agreed in it not to sell or allow to be cut any trees except those which would be marked. The penalty provided was to reimburse the Department $\$ 2.00$ per thousand feet, estimated, for the estimating and marking service. Approximately 20 per cent of the volume of trees over $10^{\prime \prime}$ D.B.H. was marked for cutting. 
The trees were marked by an axe blaze at breast height and on the stump, and the stump blaze was stamped with a scaler's hammer as a precaution against unauthorized cutting. Two hundred and thirty-three trees were so marked, giving an estimated Doyle volume of 46,890 board feet by ocular estimate; 47,600 board feet by the Form Class 79 Volume Tables of Mesavage and Girard; and 50,200 board feet by the empirical volume tables developed at Cooperstown. The marked trees were tabulated by species and diameter classes on mimeographed forms which would serve as a guide to interested purchasers. The lowest of the three estimates was included.

At this point in the project, governmental assistance ceased. The owner was assisted from this stage on by a Timber Agent who acted as the owner's agent in the actual marketing. The Department of Lands and Forests selected a man in the community who was respected by the local landowners and operators, and who had a knowledge of woods operations and wood marketing. Mr. Roy Hughes of Ostrander, Ontario, who had farmed and been in the wood business himself for many years, consented to act as Timber Agent in this experiment. $\mathrm{He}$ and Mr. Kauk entered into a written agreement in which the Timber Agent agreed to solicit tenders from buyers at his own expense, to draw up a sale contract which would protect the owner and his woodlot, to obtain a cash bond from the buyer, to check on cutting operations periodically, and to measure the wood and collect payment for same before it was removed from the property. As payment for his services, he was to receive 10 per cent of the gross receipts from the sale. From the Zone Forestry Office, the Timber Agent obtained a list of the local stumpage and sawlog operators. To them he mailed the mimeographed forms which gave an estimate of the volume of saw timber and the size distribution of each species. The operators were invited to inspect the standing timber and to submit bids to the agent on stumpage.

Due to the excellence of the timber and the high percentage of red oak and white pine, many operators expressed interest in purchasing the stumpage. Several of these lost interest when advised that it was necessary to sign the rather rigid contract drawn up. This contract was based on the standard contract in use in the New Jersey scheme and was perhaps a little more demanding than anything which they had encountered to date. Some of the stipulations were as follows: that the Timber Agent was to have direction of the work; that all and only marked trees were to be cut with penalty provided for the cutting of unauthorized trees; that any severely damaged trees were to be cut at the request of the Timber Agent and paid for at a stated price per thousand and per cord; that the logs were to be scaled by the Timber Agent and one of the buyer's men; that the operation could be immediately stopped if violations of the contract occurred; and that a cash deposit was to be given as a guarantee of faithful performance of the contract. Three tenders were received from operators willing to sign such a contract. The cutting rights were secured by the N. O. Hipel Lumber Company of Preston, Ontario. Through this competitive system, the prices obtained were considerably better 
than average for this area. Per thousand board feet Doyle log scale, they were as follows:

White and Red Oak

White Ash, Basswood, Soft Maple and Hard Maple

60.00

White Pine

Hemlock

45.00

Beech

The tops from the cut trees and any wood which could not be made into logs were to be cut into fuelwood, and the price obtained for this was $\$ 4.00$ per standard cord for hardwood and $\$ 1.00$ per standard cord for softwood.

A $\$ 100.00$ deposit was made and cutting operations commenced during the winter of 1948-49. Cutting was carried out with despatch and care, and turned out satisfactorily for all concerned. The operator expressed satisfaction with the system and the way in which the agent supervised the operation. The logs scaled 49,712 board feet, which was approximately 3,000 feet greater than the estimate given. The material showed very little defect except in those trees which were obviously defective when standing.

The owner of the bush was well satisfied. The stumpage on 49,712 board feet brought a return of $\$ 2,754.73$. From $191 / 4$ cords of softwood and $377 / 8$ cords hardwood, value of $\$ 170.75$ was received. The quantity of fuelwood would have been considerably higher had not the owner decided to reserve some of the tops for himself. From this sale Mr. Kauk realized personally a net value of $\$ 2,636.93$ after the Timber Agent's commission was deducted. From $1 / 15$ of his farm acreage, by the one partial cutting, he had liquidated over $1 / 4$ of the price which he had paid for the whole farm including buildings. What pleased him equally was that he had not killed the goose that laid the golden egg. On the contrary, this woodlot is in better growing condition than before, for most of the large trees which yield a low financial return were removed, and the space given over to the younger, thriftier money-makers. The remaining size distribution and the growth rate are such that another commercial cutting of about 25,000 board feet will be possible twenty years from now.

The Timber Agent's work was not excessively demanding of his time. His remuneration amounted to almost $\$ 300.00$. Out of this, he paid for the advertising necessary to attract bids, mailing, telephone calls and his personal travelling expenses. He was well satisfied and expressed a definite interest in continuing this type of endeavour.

From this project, the writer received valuable insight into the problem of selling forest products. A by-product of the work was the check it afforded on the estimation of volume of standing timber. Zone Foresters frequently need a practical, simple volume table, which will give a timber estimate with a fair degree of accuracy. This experiment and several other subsequent checks have shown that for estimates over 10,000 board feet, the so-called Cooperstown Volume Tables Doyle Rule are very satisfactory. These tables have only two variables, namely, species and 2-inch diameter classes 
and one set of tables gives a reduced volume to allow for cull. Using the tables with a cull allowance in this experiment, the estimate was high by only 488 board feet.

This experiment has shown both the value and the need for some type of marketing assistance. It resulted in at least one convert to partial cutting and organized marketing. Following a write-up of this experiment in one of the farm magazines, inquiries about obtaining this service were received from many parts of Ontario and from several other provinces. Evidently a great many woodlot owners would appreciate help in selling their timber and fuelwood. The use of a timber agent brings some such marketing scheme well within the scope of a government forestry agency, and also eliminates the necessity of spoon-feeding the owner with free services. The Ontario Department of Lands and Forests has recently completed a market survey of wood-using industries throughout Southern Ontario. A complete list of outlets is therefore available to woodlot owners and primary wood processors. This is an important step forward toward efficient and more profitable marketing. Coupled with a program of assistance such as was rendered in the afore-mentioned experiment, forest farming would become more profitable, and hence more widespread. 